\title{
1 Sexual maturation in Atlantic salmon male parr may be triggered both 2 in early spring and late summer under standard farming conditions
}

4 Elia Ciani ${ }^{1}$, Kristine von Krogh ${ }^{1}$, Rasoul Nourizadeh-Lillabadi ${ }^{1}$, Ian Mayer ${ }^{2}$, Romain 5 Fontaine $^{1}$, Finn-Arne Weltzien ${ }^{1 *}$

7 Norwegian University of Life Sciences, Faculty of Veterinary Medicine, ${ }^{1}$ Department of Basic

8 Science and Aquatic Medicine, ${ }^{2}$ Department of Production Animal Clinical Sciences. 0454 Oslo, 9 Norway

10

$11 *$ Corresponding author: finn-arne.weltzien@ nmbu.no; tel +47 67232036 


\section{Abstract:}

13 Male Atlantic salmon (Salmo salar) display different sexual strategies, maturing either as parr 14 during the freshwater phase (as sneaky spawners), or as post smolts following one or several years 15 at sea. First sexual maturation (puberty) occurs at different times depending on environmental and 16 genetic factors. To improve our knowledge on the timing (age and season) of first sexual 17 maturation in Atlantic salmon male parr, we investigated pubertal activation in second generation 18 farmed salmon from the Norwegian river Figgjo, reared under natural conditions of photoperiod 19 and water temperature. Histological analysis, in combination with morphometric measurements, 20 plasma androgen levels and pituitary gonadotropin gene expression analysis revealed that, as 21 previously reported, some male parr initiated early sexual maturation in spring at one year of age. 22 Interestingly, some male parr were observed to initiate sexual maturation already in autumn, six 23 months after hatching (under-yearlings), much earlier than reported in previous studies. One-year 24 old maturing males showed a low induction in gonadotropin levels, while under-yearling maturing 25 males displayed a significant increase in $f s h b$ transcripts as compared to immature fish. Plasma 26 testosterone, detectable also in immature males, increased constantly during testes development, 27 while 11-ketotestosterone, undetectable in immature and early maturing males, increased during 28 more advanced stages of maturation. A mild feminization of the testes (ovotestes) was detected in 29 a subset of samples. This study brings new knowledge on the little investigated field of sexually 30 maturing under-yearlings in Atlantic salmon. This is also the first study comparing the physiology

31 of under-yearling vs one-year old maturing male parr, thus bringing new insights to the remarkable 32 plasticity of Atlantic salmon puberty.

34 Keywords: Atlantic salmon, follicle-stimulating hormone, luteinizing hormone, testosterone, 1135 ketotestosterone, precocious parr 


\section{Introduction}

Puberty is a process of physical and physiological changes through which an individual reaches sexual maturation for the first time in life. In male teleosts, as in other male vertebrates, puberty is characterized by the onset of spermatogenesis (Schulz and Miura, 2002). Spermatogenesis is regulated by the brain-pituitary-gonadal (BPG) axis, with the pituitary producing the gonadotropins, follicle-stimulating hormone (Fsh) and luteinizing hormone (Lh), which are key hormones involved in the control of gonadal maturation (Levavi-Sivan et al., 2010).

Fsh and Lh are heterodimeric glycoproteins consisting of two non-covalently linked subunits, a common $\alpha-(\mathrm{Gp} \alpha)$, and a hormone-specific $\beta$-subunit $(\operatorname{Lh} \beta$ or Fsh $\beta)$ that confers the biological activity (Pierce and Parsons, 1981; Swanson et al., 2003). Unlike mammals, where both gonadotropins are produced from the same pituitary cell, Fsh and Lh in teleosts are mostly produced from two different cell types, located in the proximal pars distalis (PPD) of the pituitary gland (Fontaine et al., 2020a; Levavi-Sivan et al., 2010; Weltzien et al., 2004).

The physiological role of gonadotropins has been extensively studied in salmonids (Gomez et al., 1999; Maugars and Schmitz, 2008, 2006; Prat et al., 1996; Swanson et al., 1989). In males, Fsh and Lh induce the production of the androgens 11-ketotestosterone (11-KT) and testosterone (T) with similar efficacy during early stages of maturation (Planas et al., 1993; Planas and Swanson, 1995). 11-KT, which is the main androgen in salmonids (Borg, 1994; Rege et al., 2019), plays a major role in all stages of teleost spermatogenesis, being involved in the induction of spermatogonial proliferation, meiotic division and spermiogenesis (Miura et al., 1991). $\mathrm{T}$ is involved in several feedback mechanisms to the hypothalamus (Amano et al., 1994; Fontaine et al., 2020b; Goos et al., 1986) and pituitary (Fontaine et al., 2020b; Montero et al., 1995; Xiong et al., 1993), and can act through both the androgen receptor (Ar) and the estrogen receptors (Ers). In addition, Lh is a potent stimulator of the maturation-inducing steroid 17 $\alpha, 20 \beta$-dihydroxy-4pregnen-3-one (DHP) during the last stages of maturation in both sexes (Planas and Swanson, 61 1995).

In salmonids, plasma Fsh levels increase already during the onset of spermatogenesis, earlier than Lh plasma levels, which remain undetectable or very low during the initial stages of maturation and rises only during spermiation (Swanson et al., 2003). It has been suggested that Fsh, due to its presence in the plasma of immature fish and its capacity to stimulate both steroidogenesis and spermatogonial proliferation (Loir, 1999), plays a major role during the early stages of gonadal development in salmonids, while $\mathrm{Lh}$ is more involved in the later stages of maturation (Levavi-Sivan et al., 2010; Schulz et al., 2010; Yaron et al., 2003).

The anadromous Atlantic salmon (Salmo salar) shows remarkable plasticity concerning male sexual maturation. Males may mature either during the freshwater phase (parr), from one to

71 four years of age, as small "sneaky spawners/precocious males" (Aas et al., 2011), or in the 72 saltwater phase following smoltification at a larger size as one- (grilse) or multi-sea-winter 
73 individuals (Garcia De Leaniz et al., 2007; Hutchings and Jones, 1998; Taylor, 1991). There has

74 also been occurrences of male parr maturation earlier than one year of age (under-yearling or 0+)

75 both in wild (Bagliniere and Maisse, 1985) and farmed populations reared under artificial light

76 regimes (Nordgarden et al., 2007). However, little is known about the physiology of under-yearling

77 maturing males regarding gonadotropin expression, testes development or morphometric profiles.

78 Here, we recorded the timing of seasonal sexual maturation in farmed Atlantic salmon male parr

79 reared in south-west Norway under natural conditions of photoperiod and water temperature. The

80 aim was to assess the specific time and age at which sexual maturation is initiated and to compare

81 the physiology of fish maturing as under-yearling or as one-year old individuals. 


\section{Material and Methods}

\subsection{Animals and rearing conditions}

One-year old Atlantic salmon male parr were sampled in spring/summer 2017 (batch 1), in addition to a batch of under-yearling (four months old) parr in summer/autumn 2017 (batch 2). The broodstock was a farmed first generation from wild caught fish in the river Figgjo (south-west Norway, $58^{\circ} 47^{\prime} \mathrm{N} 5^{\circ} 47^{\prime} \mathrm{E}$ ). The fish were reared at the Norwegian Institute for Nature Research (NINA) salmon research station at Ims, Norway $\left(58^{\circ} 54^{\prime} \mathrm{N}, 5^{\circ} 57^{\prime} \mathrm{E}\right)$, hatching on February $22^{\text {nd }}$, 2016 (batch 1), and March 14 ${ }^{\text {th }}, 2017$ (batch 2). After first feeding, fish were reared in outdoor tanks (volume $7.8 \mathrm{~m}^{3}$ ), under natural conditions regarding photoperiod and temperature (Supplementary figures S1, S2). All experiments were performed in accordance with guidelines of the Animal Welfare Committee of the Norwegian university of life sciences (NMBU) and of the European Union regulation concerning the protection of experimental animals (Directive 2010/63/EU). Appropriate measures were taken during sampling to minimize pain and discomfort (FOTS application ID12523).

\subsection{Sampling}

Fish were anesthetized with MS222 (80 mg/l; Pharmaq, Overhalla, Norway) and euthanized via quick decapitation. Body weight, gonad weight and fork length were measured for all fish. Gonadosomatic index (GSI = gonad weight / body weight x 100) and condition factor (K $=100$ body weight $/$ fork lenght ${ }^{3}$ ) were calculated from the morphometric measurements. As testes size increases at puberty, the gonad somatic index was used to initially divide males as either immature or maturing before additional analysis. The fish were divided into two groups based on GSI and morphology: one group with immature thread-like testes (GSI < 0.05), and a second group showing the first signs of testicular development (GSI > 0.05). Without a universal criterion within the literature for a threshold GSI value to classify males as immature (Duston and Saunders, 1999; Endal et al., 2000; Kadri et al., 1997), we initially classified males with GSI $\leq 0.05$ as immature while those with GSI $>0.05$ as maturing. This threshold is also supported by our histology results as shown below. Fish were sampled until a minimum of six biological replicates per group were obtained (Table 1,2). One year old parr (14 months old at first sampling) were sampled from April to July 2017 ( $25^{\text {th }}$ April; $8^{\text {th }}$ and $23^{\text {rd }}$ May; $7^{\text {th }}$ June; $4^{\text {th }}$ July) while under-yearling parr (4 months old at first sampling) were sampled from July to October 2017 ( $4^{\text {th }}$ July; 22 ${ }^{\text {nd }}$ August; 27 ${ }^{\text {th }}$ September; $23^{\text {rd }}$ October).

\subsection{Testis histology}

Testes from all sampled fish were dissected and fixated in $4 \%$ glutaraldehyde (VWR, Radnor, USA) overnight at $4{ }^{\circ} \mathrm{C}$. The samples where then stored in $70 \%$ ethanol (EtOH) at $4{ }^{\circ} \mathrm{C}$ until further processing. Histological analyses were performed as follows: tissues were dehydrated with EtOH washes at increasing concentrations (up to $100 \% \mathrm{EtOH}$ ), each lasting $30 \mathrm{~min}$. The last step was repeated three times. Tissues were then kept at room temperature overnight slowly 
shaking in preparation solution (100 ml Technovit 7100 added $1 \mathrm{~g}$ of Hardener I (Heraeus Kulzer, Hanau, Germany)). Afterwards, tissues were embedded in cold Histoform S (Heraeus Kulzer) added approx. one $\mathrm{mL}$ preparation solution with $50 \mu \mathrm{L}$ Hardener II (Heraeus Kulzer) and incubated at $37^{\circ} \mathrm{C}$. Finally, samples were mounted on Histoblocs using Technovit 3040 (both from Heraeus Kulzer).

Sagittal (for small and medium testes) and transverse (for large testes) sections, $3 \mu \mathrm{m}$ thick, were prepared using a Leica RM2245 microtome (Leica Biosystems, Wetzlar, Germany). Sections were separated by at least $30 \mu \mathrm{m}$ and collected from the periphery until the middle of the tissue. Dried sections were stained with Toluidine Blue O (Sigma-Aldrich) and mounted with Coverquick 4000 (VWR International, Radnor, PA, USA) before histological analysis. The maturational stages of the testes were determined by the most advanced germ cell present in the tissue (Table 4). Germ cell stages were defined according to the description by Melo et al. (2014). Histological analyses were performed in all maturing and two randomly selected immature fish per time point. At least five sections per testes were analysed.

\subsection{Gene expression analysis}

Individual pituitaries from at least six maturing and six immature fish per time point were collected and stored in $300 \mu \mathrm{l}$ TRIzol reagent (Invitrogen, Waltham, USA) overnight at $4{ }^{\circ} \mathrm{C}$, then at $-20{ }^{\circ} \mathrm{C}$. Total RNA was isolated using TRIzol reagent according to the manufacturer's instructions. To avoid any genomic contamination, extracted RNA was treated with 2 U DNase (TURBO DNA-free kit, Ambion, Foster City, USA). The concentration of total RNA was measured via Qubit Fluorometer (Invitrogen) using Qubit RNA BR Assay Kit (Invitrogen). The 260/280 ratio for all samples was between 1.8 and 2. Quality of RNA samples was measured using Bioanalyzer 2100 (Agilent, Santa Clara, USA). All samples showed RNA Integrity Number (RIN) above 8. SuperScript III reverse transcriptase (Invitrogen) and $5 \mu \mathrm{M}$ random hexamer primers (Invitrogen) were used, following producer's instructions, to reverse transcribe $170 \mathrm{ng}$ total RNA from individual pituitaries.

Primer-Blast from NCBI website (Ye et al., 2012) was used to design specific qPCR primer sets for the genes of interest (Table 3). Primers were tested for primer dimers and hairpin potential with Vector NTI Express software (Lu and Moriyama, 2004). Gene expression of the target genes $f_{s h} b$ and $l h b$ was quantified by qPCR using the Light Cycler 96 (Roche, Basel, Switzerland) thermocycler and SYBR Green I master (Roche) kit as shown in Weltzien et al. (2005). In brief, each individual sample was run in duplicate using $3 \mu \mathrm{L}$ of the same cDNA dilution 1/10. A negative control and an inter-plate calibrator were present in triplicate for each qPCR plate. Realtime conditions were 10 min incubation at $95{ }^{\circ} \mathrm{C}$ followed by 40 cycles at $95{ }^{\circ} \mathrm{C}$ for $10 \mathrm{~s}, 60{ }^{\circ} \mathrm{C}$ for $10 \mathrm{~s}$, and $72{ }^{\circ} \mathrm{C}$ for $8 \mathrm{~s}$. The specificity of the amplified product was verified by running a melting curve analysis and by sequencing of the PCR product. Standard curves were run in triplicates using dilution series obtained from RT products from pooled total RNA of pituitaries. The relative abundance of transcript was determined using GenEx software (Mangalam et al., 
157 2001) through the algorithms outlined by Vandesompele et al. (2002). The reference genes used

158 for data normalization were rnal8s and efla. Stability of the reference genes was tested using the

159 online tool RefFinder (Kim et al., 2010).

\subsection{Radioimmunoassay (RIA)}

Blood from all sampled fish was collected from the caudal vein with heparinised (SigmaAldrich) syringes. Plasma was then isolated by centrifugation and stored at $-80{ }^{\circ} \mathrm{C}$. Levels of $\mathrm{T}$ and 11-KT were measured by specific radioimmunoassay (RIA) as previously described by Mayer et al. (1990). Standard curves were prepared mixing steroid solutions containing decreasing concentrations of the respective, non-radioactive steroid in $\mathrm{pH} 7.0$ RIA buffer $\left(\mathrm{NaH}_{2} \mathrm{PO}_{4} 3.87 \mathrm{~g}\right.$,

167 for $\mathrm{T}$ and 11-KT were 13.5 and $14 \%$, while the intra-assay variations were 5.6 and $4.8 \%$ 168 respectively. The analysis of 11-KT plasma levels were prioritised when the amount of plasma 169 isolated was not sufficient for both analysis. Due to the small size of the fish and the insufficient 170 amount of plasma available, RIA was not performed on underyearling fish (Table 1,2)

\section{$171 \quad 2.6$ Statistics}

All statistical analyses were performed with JMP pro V14.1 software (SAS Institute Inc.,

173 Cary, NC, USA). Shapiro-Wilk W test was used for testing normality and Quantile Range method

$174(\mathrm{Q}=3$; Tail 0.1) was used to identify and exclude outliers. When needed, data were log transformed 175 to meet test criteria. Variations in morphometric data and gene expression during sexual 176 maturation were analysed for statistical significance by two-way ANOVA, followed by Tukey's 177 HSD test. Variations in gene expression relative to testes developmental stage were assessed using 178 one-way ANOVA, followed by Tukey's HSD test. In this study, p values < 0.05 were considered 179 statistically significant. 


\section{Results}

All results of the present study are summarised in Table 1 and Table 2. All values are reported in the following chapter as mean \pm SEM.

\subsection{Testes histology}

Examples of the testes developmental stages identified in the present study ( $-\mathrm{VI})$, are presented in Fig. 1 (A-F). All fish classified as immature according to GSI $\leq 0.05$, had stage I testis, indicating that active spermatogenesis had not started, and only spermatogonia type A cells were present in the tissue. In contrast, in all males with GSI > 0.05, testis development had progressed into stage II to IV, indicating that active spermatogenesis had started, with spermatogonia type B cells, spermatocytes and spermatids found in the testicular lobules. This classification, based on GSI, was used to categorize between non- and maturing fish.

In one-year old maturing fish, the testes development had reached stage II already by the first sampling on April 25 ${ }^{\text {th }}$ (Fig 2A). On May $8^{\text {th }}$, stage II and III testes were predominantly detected, although a few individual had developed into stage IV, V and VI. The occurrence of the most advanced stages (IV to VI) increased during the season, and on July $4^{\text {th }}$, only stage V and VI were detected in the examined tissue (Fig 2A). Of note, histologically, a stage IV testis with residual spermatozoa is not distinguishable from a stage V. Similarly, as stage V and VI include spermatozoa, we did not distinguish residual from new spermatozoa. Interestingly, the presence of residual spermatozoa (Fig 3A) was observed in 6 out of 27 (22.2\%) testes at stages I, II and III, lacking one or more intermediate germ cell stages suggesting that complete maturation has already performed by those fish previously. Thus in the rest of the study, we have investigated both oneyear old and under-yearling fish.

In under-yearling males, the first signs of testis maturation beyond proliferating SPA were detected on September $27^{\text {th }}$, with testes stages spanning from II to V. By October $23^{\text {rd }}$, all examined samples had reached full maturation (stage V and VI) (Fig 2B).

There were some peculiarities detected in the histological analysis. First, the presence of previtellogenic oocytes within the testis tissue (Fig 3B) was observed in 6 out of $69(8.7 \%$ ) analysed testes, and this occurred in both under-yearlings and one-year old fish. It is possible that the absolute number of fish with testis-ova may be higher as we did not analyse all the tissue from each testis, and furthermore, that oogonia and peri-nucleolar oocytes can be difficult to distinguish from undifferentiated spermatogonia Type A by histology alone. Second, in several testes from both one-year old and under-yearling maturing males, an incomplete tissue development with part of the testes fully developed and others being completely immature, was detected (Supplementary figure S3). 


\subsection{Biometry}

One-year old maturing fish (GSI > 0.5) were already identified from the first sampling on April $25^{\text {th }}$ (Fig 4A). Maturing and immature fish display no significant differences in fork length (Fig 4B) and body weight (Fig 4C) except on May $23^{\text {rd }}$, where mature fish have increased fork length and body weight. No differences between groups at any time point are detected for condition factor (Fig 4D). Due to the lower number of parr available in the batch and the high percentage of maturing fish within the parr population, only one immature individual is present on June $7^{\text {th }}$. Data from this fish are shown in figure 1 for graphical purposes only but are not included in the statistical analysis. All fish sampled on July $4^{\text {th }}$ were classified as maturing.

Under-yearling maturing fish (GSI $>0.5)$ were detectable from September $27^{\text {th }}$, six months after hatching (Fig 5A). No statistically significant differences were measured between groups in fork length at any time point (Fig 5B), while immature fish displayed greater body weight compared to maturing fish on September $27^{\text {th }}$ (Fig 5C). No differences in condition factor were detected between groups (Fig 5 D).

\subsection{Seasonal gonadotropin expression}

In one year old maturing males pituitary $f s h b$ mRNA levels remained stable over time (from April $25^{\text {th }}$ to July $4^{\text {th }}$ ) while they decreased in immature fish from April $25^{\text {th }}$ to May $23^{\text {rd }}$. On May $23^{\text {rd }}$, maturing fish displayed higher $f s h b$ transcripts than immature fish (Fig 6A). Pituitary lhb mRNA transcripts decreased over time in both maturing and immature fish from April to May/June. Significantly higher $l h b$ mRNA levels are detected in maturing fish as compared to in immature fish only on May $23^{\text {rd }}$ (Fig 6C).

In under-yearling immature fish stable $f s h b$ mRNA levels were observed in July/August, then decreased from August $22^{\text {nd }}$ to October $23^{\text {rd }}$. Maturing fish, which were first identified on September $27^{\text {th }}$, had stable $f s h b$ transcript levels until last day of sampling on October $23^{\text {rd }}$. Maturing fish showed higher $f s h b$ mRNA levels than immature fish, from the date they were first identified to the end of the sampling period (September $27^{\text {th }}$ to October $23^{\text {rd }}$; Fig $6 \mathrm{~B}$ ). Both maturing and immature fish show stable $l h b$ mRNA levels over time between July $4^{\text {th }}$ and October $23^{\text {rd }}$. No differences in $l h b$ mRNA abundance are detected between groups at any time point (Fig 6D).

\subsection{Androgens plasma levels}

Plasma levels of $\mathrm{T}$ and 11-KT were measured only in one year old fish. T levels of oneyear old maturing parr increased over time from $0.74 \pm 0.07 \mathrm{ng} / \mathrm{mL}$ on April $25^{\text {th }}$, to $1.72 \pm 0.16$ $\mathrm{ng} / \mathrm{mL}$ on July $4^{\text {th }}$, while remaining stable between 0.2 to $0.3 \mathrm{ng} / \mathrm{mL}$ in immature fish during the same period. Maturing fish showed statistically significant higher $\mathrm{T}$ plasma level than immature fish on May $8^{\text {th }}$ and $23^{\text {rd }}$ (Fig 7A). In contrast, 11-KT plasma levels remained below the detection limit $(0.1 \mathrm{ng} / \mathrm{mL})$ throughout the season (Fig 7B) in immature fish and increased from non- 
250 detectable (below $0.1 \mathrm{ng} / \mathrm{mL}$ ) in almost all maturing males on April $25^{\text {th }}$ to $2.07 \pm 0,57 \mathrm{ng} / \mathrm{mL}$ on 251 July $4^{\text {th }}$.

\section{$252 \quad 3.5$ Characterization of testis developmental stages}

253 For the subsequent analysis of changes in gonadotropins mRNA levels, GSI and steroid 254 plasma levels, the fish were grouped according to their testis developmental stage. .

A significant increase in $f$ sh $b$ transcripts was detected between stage I and stage II-to-IV 256 (2.1- to 4.8-fold increase, Fig 8A). Fish in stages II, III and VI showed significantly higher lhb 257 mRNA levels compared to stage I individuals (3.7- to 7.2-fold increase Fig. 8B). Fish at stage I 258 had average GSI < $0.05(0.032 \pm 0.004)$. This value increased between 0.2 to 0.4 at stages II to V 259 and rose to 1.95 at stage VI (Fig. 8C). 11-KT plasma content remained below detection limit (0.1 $260 \mathrm{ng} / \mathrm{mL}$ ) in all (except one) stage I, II and III fish. Values ranging from $0.30 \pm 0.13 \mathrm{ng} / \mathrm{mL}$ (stage $261 \mathrm{IV}$ ) to $1.34 \pm 0.43 \mathrm{ng} / \mathrm{mL}$ (stage VI) were detected in more advanced stages, but with no 262 statistically significant differences between groups, likely due to the high variation between 263 individuals (Fig. 8D). Plasma T levels, on the other hand, were detectable in some fish from stage $264 \mathrm{I}(0.27 \pm 0.12 \mathrm{ng} / \mathrm{mL})$, steadily increasing up to $1.43 \pm 0.12 \mathrm{ng} / \mathrm{mL}$ at stage VI (Fig. 8E). 


\section{Discussion}

This study investigates timing and age of sexual maturation in Atlantic salmon male parr in a farmed second generation from wild caught from the river Figgjo (South-west Norway), reared under natural photoperiod and water temperature.

Atlantic salmon spawns in autumn/winter with gonadal maturation in male parr occurring months earlier, generally in spring (Aas et al., 2011). In the present study, one year old male parr showed first sign of sexual maturation in spring, starting before the end of April. This is earlier than what has been previously reported. For instance, (Maugars and Schmitz, 2008) reported the first signs of maturation in male parr in early June, and Mayer et al. (1990) in July. In these studies, the fish, belonging to different strains, were reared at a higher latitude compared to our study $\left(63^{\circ}\right.$ $\mathrm{N}$ vs $58^{\circ} \mathrm{N}$ ), thus experiencing different environmental conditions. The variability in the maturation period between different strains, breeding in different rivers, is a known characteristic of Atlantic salmon, aimed at synchronising reproductive behaviour with the surrounding environment (Aas et al., 2011). However, despite the numerous studies investigating the link between environment, genetic background and sexual maturation, a detailed understanding of the molecular mechanism involved in the regulation of puberty in Atlantic salmon is still missing.

The levels of gonadotropin mRNA found in the one-year old males were also peculiar, as no statistically significant differences were detected between maturing and immature fish (except on May $23^{\text {rd }}$ ), despite a tendency for higher abundance in maturing males. In salmonids, both $f s h b$ mRNA and Fsh protein plasma levels increase during the early stages of maturation, at the onset of spermatogenesis, while $l \mathrm{hb}$ mRNA and Lh plasma protein levels are very low or undetectable at this early stages, increasing significantly toward the spawning season (Campbell et al., 2003; Gomez et al., 1999; Planas and Swanson, 1995; Swanson et al., 1991). It is possible that biologically relevant differences might have been too small to be statistically significant, or that a peak in gonadotropin mRNA levels had occurred outside the sampling period. On the other hand, plasma $\mathrm{T}$ and 11-KT concentrations increased gradually in maturing males while remaining at stable lower levels $(\mathrm{T})$ or undetectable (11- KT) in immature males, in concert with their role in sexual maturation (Fontaine et al., 2020b; Schulz et al., 2010). While androgen plasma concentrations are comparable with previous studies (Maugars and Schmitz, 2008; Mayer et al., 1990a; Stuart-Kregor et al., 1981), the androgen increase observed in maturing males occurred 12 months earlier in the year than what has been reported previously, but consistent with the observed increase in GSI. Histological analyses confirmed the advancement in testis development in fish with GSI > 0.05 (ranging from stage II to VI) and the presence of only spermatogonia type A (SPA; stage I) in the testis of fish with GSI $\leq 0.05$. In the present study, testis exhibiting either, or both, undifferentiated (SPA und $_{\text {) }}$ and differentiated (SPA diff $)$ SPA cysts were included in stage I. However, a number of recent studies (Crespo et al., 2019; Kjærner-Semb et al., 2018; Melo et al., 2014; Schulz et al., 2019; Skaftnesmo et al., 2017) have shown that detecting and quantifying proliferating SPA allows identification of males who have initiated sexual maturation even at this 
early stage. It is therefore possible that some of our stage I samples include fish that indeed have entered the maturation process. Such analysis was not performed here as residual spermatozoa were detected in a subset of the one-year old maturing males, thus suggesting that for some fish sexual maturation had been initiated for the first time at a younger age, and that these fish were maturing for the second time at this stage. To determine the age of first maturation for this subgroup, we sampled under-yearling fish next.

Under-yearling males showed the first signs of sexual maturation in autumn, as early as six months after hatching. As expected, maturing under-yearlings, initially grouped by a GSI $>0.05$, displayed a 25 - to 115 -fold induction in pituitary $f_{s} h b$ mRNA levels, but not $l h b$ mRNA transcripts, compared to immature fish. As previously mentioned, in salmonids, $f s h b$ mRNA transcripts peak during early stages of maturation, while $l h b$ mRNA are very low or undetectable, rising instead toward the spawning season and sperm maturation (Campbell et al., 2003; Gomez et al., 1999; Planas and Swanson, 1995; Swanson et al., 1991). Concomitant with the increase in $f$ shb mRNA level, histological analyses confirmed the advancement in testis development, ranging from stage II to V in September. Maturing fish reached stage VI, characterised by the predominant presence of spermatozoa in the testes, in October. Such advanced testis development suggests that it is unlikely that these fish were undergoing a "dummy run", which is characterized by an incomplete activation of the BPG-axis (Okuzawa, 2002). Interestingly, maturing males reached the final stages of testis development in autumn, during the natural spawning season in Scandinavian rivers (Aas et al., 2011). In the wild, sexually maturing under-yearling male parr have been identified (by milt production) in Atlantic salmon in a number of rivers in the Armorican massif, in northwest France, most likely due to the higher temperatures found in this system (Bagliniere and Maisse, 1985). While under-yearling maturation could be induced by photoperiod manipulation (LD 12:12 followed by LD 24:0) in a population of farmed Atlantic salmon in western Norway (Nordgarden et al., 2007), the present study now demonstrates that under-yearling sexual maturation can also occur under standard farming condition, using natural photoperiod and water temperature.

For further characterisation of the physiological conditions of male parr during development, gonadotropin mRNA levels, GSI and steroid plasma levels were measured between the different testis developmental stages, pooling both age groups together. A statistically significant 2- to 6-fold increase in pituitary $f s h b$ transcripts was detected between stage I and the more advanced stages (II-VI). This is a lower induction compared to other studies conducted on maturing parr (Maugars and Schmitz, 2008) and smolt (Melo et al., 2014), showing a 20- to 60and 100- to 200-fold increase respectively. Similarly, the relative abundance of lhb transcripts detected in the present study showed an 8-fold induction between stage I and VI while increases of 100- or 600-fold was reported in the aforementioned studies. While circulating steroids levels also increased from early to late developmental stages, the measured concentrations were generally lower compared to previous studies. In particular 11-KT levels remained below detection limit in most fish up to developmental stage III, when spermatogonia (type A and B) and spermatocytes are already present in the testes. This was unexpected, as 11-KT is involved in germ cell maturation 
and proliferation (Schulz et al., 2010). However, the measured plasma 11-KT acting as endocrine messenger to target organs, may differ from in situ levels in the testes acting as paracrine signal to promote germ cell maturation. Despite the values of the investigated parameters being lower than expected, testis development proceeded up to later stages of maturation. The comparison of our results with the literature indicates a high level of variability between studies. Our results also suggest that small variations in gonadotropin transcripts and androgen plasma levels might suffice to promote sexual maturation.

Histological analyses revealed the presence of early previtellogenic oocytes in $8.7 \%$ of testes analysed, including both under-yearling and one-year old fish. The intersex condition has been documented in different gonochoristic (fixed-sex) teleost species in both wild and laboratory animals (Bahamonde et al., 2013) and is considered as a characteristic effect of exposure to endocrine disrupting compounds, most commonly estrogenic chemicals (Metcalfe et al., 2010). In male rainbow trout (Oncorhynchus mykiss), exposure of estrogenic compounds elicit a dosedependent synthesis of vitellogenin and a concomitant inhibition of testicular growth (Jobling et al., 1996) and gonadal intersex (Depiereux et al., 2014). Intersex as a natural phenomenon in the wild is very challenging to evaluate given the difficulty to find pristine, uncontaminated reference sites but also due to the influence of the season of sampling age and maturity state of the animal (Bahamonde et al., 2013). The available data suggest that in salmonids, the disorder has a very low occurrence as spontaneous intersex has been reported in only 1 individual over 2660 chinook salmon (Oncorhyncus tshawytscha) sampled over 3 years in New Zealand and 3000 coho salmon (Oncorhyncus. kisutch) in Chile (Kinnison et al., 2000). The low natural occurrence of intersex in salmonids suggests that the feminization reported in the present study could be indicative of contamination from endocrine-disruptive compounds in the water. However, in those testes exhibiting ovotestis characteristics, there was only a few scattered oocytes present in the tissue suggesting the occurrence of only a mild estrogenic effect.

\section{Conclusion}

The present work represents an investigation on early sexual maturation in Atlantic salmon male parr. The timing and characterization of testes development were determined by measuring key morphometric and physiological traits in both maturing and non-maturing male parr over two consecutive seasons. These traits, established indicators of sexual maturation, included morphometric parameters [body weight, fork length, gonad weight, gonadosomatic index (GSI) and condition factor $(\mathrm{K})$ ], plasma steroids levels $(\mathrm{T}, 11-\mathrm{KT})$, gonadotropin gene expression levels $(f s h b, l h b)$ and testes developmental stages. The analyses revealed that male parr can mature in Autumn, as early as six months after hatching. In spring, at one year of age, gonadal maturation is activated, including both fish that matured as under-yearlings and first-time maturing parr. This study highlights the importance of histological analyses when investigating pubertal activation in salmonids. This is the first study comparing the physiology of under-yearling and one-year old 
bioRxiv preprint doi: https://doi.org/10.1101/2021.03.29.437499; this version posted March 30, 2021. The copyright holder for this preprint (which was not certified by peer review) is the author/funder. All rights reserved. No reuse allowed without permission.

379 maturing male parr, and further demonstrates the remarkable male reproductive plasticity 380 displayed by Atlantic salmon. 


\section{Acknowledgements}

The authors wish to thank the staff at the NINA Aquatic Research Station at Ims, in

383 particular Mr. Knut Aanestad Bergersen, for providing and maintaining the fish. We are grateful

384 to Dr. Gersende Maugars for her revision of the manuscript.

\section{Fundings}

This project has received funding from the European Union's Horizon 2020 research and

387 innovation programme under the Marie Skłodowska-Curie grant agreement No 642893

388 (IMPRESS) and from the Norwegian University of Life Sciences (NMBU).

\section{Declaration of interest}

390 The authors declare that they have no known competing financial interests or personal 391 relationships that could have appeared to influence the work reported in this paper.

\section{Authors contribution}

EC: Conceptualization, Methodology, formal analysis, Investigation, Writing - Original

394 Draft, Visualization. KvK: Investigation, Writing - Review \& Editing, Visualization. RNL:

395 Investigation, Methodology. IM: Investigation, Writing - Review \& Editing. RF: 396 Conceptualization, Methodology, Writing - Review \& Editing, Supervision. FAW: 397 Conceptualization, Methodology, Resources, Writing - Review \& Editing, Supervision, Project 398 administration, Funding acquisition 


\section{Bibliography}

400 Aas, Ø., Klemetsen, A., Einum, S., Skurdal, J., 2011. Atlantic salmon ecology. Blackwell Pub.

Amano, M., Hyodo, S., Urano, A., Okumoto, N., Kitamura, S., Ikuta, K., Suzuki, Y., Aida, K., 1994. Activation Of Salmon Gonadotropin-Releasing Hormone Synthesis By 17 $\alpha$-Methyltestosterone Administration In Yearling Masu Salmon, Oncorhynchus Masou. Gen. Comp. Endocrinol. 95, 374380. https://doi.org/10.1006/gcen.1994.1136

Bagliniere, J.L., Maisse, G., 1985. Precocious maturation and smoltification in wild Atlantic salmon in the Armorican massif, France. Aquaculture 45, 249-263. https://doi.org/10.1016/0044-8486(85)90274-1

Borg, B., 1994. Androgens in teleost fishes. Comp. Biochem. Physiol. Part C Pharmacol. Toxicol.

Campbell, B., Dickey, J.T.T., Swanson, P., 2003. Endocrine changes during onset of puberty in male spring Chinook salmon, Oncorhynchus tshawytscha. Biol. Reprod. 69, 2109-2117. https://doi.org/10.1095/biolreprod.103.020560

Crespo, Di., Bogerd, J., Sambroni, E., LeGac, F., Andersson, E., Edvardsen, R.B., Bergman, E.J., Björnsson, B.T., Taranger, G.L., Schulz, R.W., 2019. The initiation of puberty in Atlantic salmon brings about large changes in testicular gene expression that are modulated by the energy status. BMC Genomics 20, 475. https://doi.org/10.1186/s12864-019-5869-9

Depiereux, S., Liagre, M., Danis, L., De Meulder, B., Depiereux, E., Segner, H., Kestemont, P., 2014. Intersex occurrence in rainbow trout (Oncorhynchus mykiss) male fry chronically exposed to ethynylestradiol. PLoS One. https://doi.org/10.1371/journal.pone.0098531

Duston, J., Saunders, R.L., 1999. Effect of winter food deprivation on growth and sexual maturity of Atlantic salmon (Salmo salar) in seawater. Can. J. Fish. Aquat. Sci. 56, 201-207. https://doi.org/10.1139/f98-165

Endal, H.P., Taranger, G.L., Stefansson, S.O., Hansen, T., 2000. Effects of continuous additional light on growth and sexual maturity in Atlantic salmon, Salmo salar, reared in sea cages. Aquaculture 191, 337-349. https://doi.org/10.1016/S0044-8486(00)00444-0

Fontaine, R., Ciani, E., Haug, T.M.T.M., Hodne, K., Ager-Wick, E., Baker, D.M.D.M., Weltzien, F.A.F.A., 2020a. Gonadotrope plasticity at cellular, population and structural levels: A comparison between fishes and mammals. Gen. Comp. Endocrinol. 287, 113344. https://doi.org/10.1016/j.ygcen.2019.113344

Fontaine, R., Royan, M.R., von Krogh, K., Weltzien, F., Baker, D., 2020b. Direct and indirect effects of sex steroids on gonadotrope cell plasticity in the teleost fish pituitary. Front. Endocrinol. (Lausanne). 11, 858. https://doi.org/10.3389/fendo.2020.605068 
Garcia De Leaniz, C., Fleming, I.A., Einum, S., Verspoor, E., Jordan, W.C., Consuegra, S., Aubin-Horth, N., Lajus, D., Letcher, B.H., Youngson, A.F., Webb, J.H., Vøllestad, L.A., Villanueva, B., Ferguson, A., Quinn, T.P., 2007. A critical review of adaptive genetic variation in Atlantic salmon: Implications for conservation. Biol. Rev. 82, 173-211. https://doi.org/10.1111/j.1469-185X.2006.00004.x

Gomez, J.M., Weil, C., Ollitrault, M., Le Bail, P.Y., Breton, B., Le Gac, F., 1999. Growth hormone (GH) and gonadotropin subunit gene expression and pituitary and plasma changes during spermatogenesis and oogenesis in rainbow trout (Oncorhynchus mykiss). Gen. Comp. Endocrinol. 113, 413-428. https://doi.org/10.1006/gcen.1998.7222

Goos, H.J.T., de Leeuw, R., Cook, H., van Oordt, P.G.W.J., 1986. Gonadotropic hormone-releasing hormone $(\mathrm{GnRH})$ bioactivity in the brain of the immature rainbow trout, Salmo gairdneri: The effect of testosterone. Gen. Comp. Endocrinol. 64, 80-84. https://doi.org/10.1016/0016-6480(86)90031-6

Hutchings, J.A., Jones, M.E.B., 1998. Life history variation and growth rate thresholds for maturity in Atlantic salmon, iSalmo salar/i. Can. J. Fish. Aquat. Sci. 55 (Suppl., 22-47. https://doi.org/10.1139/cjfas-55-S1-22

Jobling, S., Sheahan, D., Osborne, J.A., Matthiessen, P., Sumpter, J.P., 1996. Inhibition of testicular growth in rainbow trout (Oncorhynchus mykiss) exposed to estrogenic alkylphenolic chemicals. Environ. Toxicol. Chem. 15, 194-202. https://doi.org/10.1897/1551-5028(1996)015<0194:IOTGIR>2.3.CO;2

Kadri, S., Thorpe, J.E., Metcalfe, N.B., 1997. Anorexia in one-sea-winter atlantic salmon (Salmo salar) during summer, associated with sexual maturation, in: Aquaculture. Elsevier, pp. 405-409. https://doi.org/10.1016/S0044-8486(96)01495-0

Kim, M., Gee, M., Loh, A., Rachatasumrit, N., 2010. Ref-Finder, in: Proceedings of the Eighteenth ACM SIGSOFT International Symposium on Foundations of Software Engineering - FSE '10. ACM Press, New York, New York, USA, p. 371. https://doi.org/10.1145/1882291.1882353

Kinnison, M.T., Unwin, M.J., Jara, F., 2000. Macroscopic intersexuality in salmonid fishes. New Zeal. J. Mar. Freshw. Res. 34, 125-134. https://doi.org/10.1080/00288330.2000.9516920

Kjærner-Semb, E., Ayllon, F., Kleppe, L., Sørhus, E., Skaftnesmo, K., Furmanek, T., Segafredo, F.T., Thorsen, A., Fjelldal, P.G., Hansen, T., Taranger, G.L., Andersson, E., Schulz, R.W., Wargelius, A., Edvardsen, R.B., 2018. Vgll3 and the Hippo pathway are regulated in Sertoli cells upon entry and during puberty in Atlantic salmon testis. Sci. Rep. 8. https://doi.org/10.1038/s41598-018-20308-1

Levavi-Sivan, B., Bogerd, J., Mañanós, E.L., Gómez, A., Lareyre, J.J., 2010. Perspectives on fish gonadotropins and their receptors. Gen. Comp. Endocrinol. 165, 412-437. https://doi.org/10.1016/j.ygcen.2009.07.019

Loir, M., 1999. Spermatogonia of rainbow trout: II. In vitro study of the influence of pituitary hormones, growth factors and steroids on mitotic activity. Mol. Reprod. Dev. 53, 434-442. https://doi.org/10.1002/(SICI)1098-2795(199908)53:4<434::AID-MRD9>3.0.CO;2-L

Lu, G., Moriyama, E.N., 2004. Vector NTI, a balanced all-in-one sequence analysis suite. Brief. Bioinform. 5, 378-388. https://doi.org/10.1093/bib/5.4.378 
Mangalam, H., Stewart, J., Zhou, J., Schlauch, K., Waugh, M., Chen, G., Farmer, A.D., Colello, G., Weller, J.W., 2001. GeneX: An open source gene expression database and integrated tool set. IBM Syst. J. 40, 552-569. https://doi.org/10.1147/sj.402.0552

Maugars, G., Schmitz, M., 2008. Expression of gonadotropin and gonadotropin receptor genes during early sexual maturation in male Atlantic salmon parr. Mol. Reprod. Dev. 75, 403-413. https://doi.org/10.1002/mrd.20767

Maugars, G., Schmitz, M., 2006. Molecular cloning and characterization of FSH and LH receptors in Atlantic salmon (Salmo salar L.). Gen. Comp. Endocrinol. 149, 108-117. https://doi.org/10.1016/j.ygcen.2006.04.011

Mayer, I., Berglund, I., Rydevik, M., Borg, B., Schulz, R.W., 1990a. Plasma levels of five androgens and 17 alpha -hydroxy-20 beta -dihydroprogesterone in immature and mature male Baltic salmon (Salmo salar) parr, and the effects of castration and androgen replacement in mature parr. Can. J. Zool. 68, 263-267.

Mayer, I., Lundqvist, H., Berglund, I., Schmitz, M., Schulz, R., Borg, B., 1990b. Seasonal endocrine changes in Baltic salmon, Salmo salar, immature parr and mature male parr. Plasma levels of five androgens, 17 $\alpha$-hydroxy-20 $\beta$-dihydroprogesterone, and 17 $\beta$-estradiol. Can. J. Zool. 68, 1360-1365. https://doi.org/10.1139/z90-203

Melo, M.C., Andersson, E., Fjelldal, P.G., Bogerd, J., Franca, L.R., Taranger, G.L., Schulz, R.W., 2014. Salinity and photoperiod modulate pubertal development in Atlantic salmon (Salmo salar). J. Endocrinol. 220, 319-332. https://doi.org/10.1530/JOE-13-0240

Metcalfe, C.D., Kidd, K.A., Sumpter, J.P., 2010. Chemically induced alterations to gonadal differentiation in fish, in: Fish Diseases and Disorders. CABI Publishing, pp. 144-165. https://doi.org/10.1079/9781845935535.0144

Miura, T., Yamauchi, K., Takahashi, H., Nagahama, Y., 1991. Hormonal induction of all stages of spermatogenesis in vitro in the male Japanese eel (Anguilla japonica). Proc. Natl. Acad. Sci. U. S. A. 88, 5774-5778. https://doi.org/10.1073/pnas.88.13.5774

Montero, M., Lebelle, N., Kingb, J.A., Millarb, R.P., Dufour, S., Le Belle, N., King, J.A., Millar, R.P., Dufour, S., 1995. Differential regulation of the two forms of gonadotropin-releasing hormone (mGnRH and cGnRH-II) by sex steroids in the european female silver eel (Anguilla anguilla). Neuroendocrinology 61, 525-535. https://doi.org/10.1159/000126876

Nordgarden, U., Björnsson, B.T., Hansen, T., 2007. Developmental stage of Atlantic salmon parr regulates pituitary GH secretion and parr-smolt transformation. Aquaculture 264, 441-448. https://doi.org/10.1016/j.aquaculture.2006.12.040

Okuzawa, K., 2002. Puberty in teleosts. Fish Physiol. Biochem. https://doi.org/10.1023/A:1023395025374

Pierce, J.G., Parsons, T.F., 1981. Glycoprotein Hormones: Structure and Function. Annu. Rev. Biochem. 50, 465-495. https://doi.org/10.1146/annurev.bi.50.070181.002341

Planas, J. V, Swanson, P., 1995. Maturation-associated changes in the response of the salmon testis to the 
steroidogenic actions of gonadotropins (GTH I and GTH II) in vitro. Biol. Reprod. 52, 697-704. https://doi.org/10.1095/biolreprod52.3.697

Planas, J. V, Swanson, P., Dickhoff, W.W., 1993. Regulation of testicular steroid production in vitro by gonadotropins (GTH I and GTH II) and cyclic AMP in coho salmon (Oncorhynchus kisutch). Gen. Comp. Endocrinol. 91, 8-24. https://doi.org/10.1006/gcen.1993.1099

Prat, F., Sumpter, J.P., Tyler, C.R., 1996. Validation of radioimmunoassays for two salmon gonadotropins

Schulz, R.W., de França, L.R., Lareyre, J.J., LeGac, F., Chiarini-Garcia, H., Nobrega, R.H., Miura, T., 2010. Spermatogenesis in fish. Gen. Comp. Endocrinol. 165, 390-411. https://doi.org/10.1016/j.ygcen.2009.02.013

Schulz, R.W., Miura, T., 2002. Spermatogenesis and its endocrine regulation. Fish Physiol. Biochem. https://doi.org/10.1023/A:1023303427191

Schulz, R.W., Taranger, G.L., Bogerd, J., Nijenhuis, W., Norberg, B., Male, R., Andersson, E., 2019. Entry into puberty is reflected in changes in hormone production but not in testicular receptor expression in Atlantic salmon (Salmo salar). Reprod. Biol. Endocrinol. 17. https://doi.org/10.1186/s12958-0190493-8

Skaftnesmo, K.O., Edvardsen, R.B., Furmanek, T., Crespo, D., Andersson, E., Kleppe, L., Taranger, G.L., Bogerd, J., Schulz, R.W., Wargelius, A., 2017. Integrative testis transcriptome analysis reveals differentially expressed miRNAs and their mRNA targets during early puberty in Atlantic salmon. BMC Genomics 18. https://doi.org/10.1186/s12864-017-4205-5

Stuart-Kregor, P.A.C., Sumpter, J.P., Dodd, J.M., 1981. The involvement of gonadotrophin and sex steroids in the control of reproduction in the parr and adults of Atlantic salmon, Salmo salar L. J. Fish Biol. 18, 59-72. https://doi.org/10.1111/j.1095-8649.1981.tb03760.x

Swanson, P., Bernard, M., Nozaki, M., Suzuki, K., Kawauchi, H., Dickhoff, W.W., 1989. Gonadotropins I and II in juvenile coho salmon. Fish Physiol. Biochem. 7, 169-176. https://doi.org/10.1007/BF00004704

Swanson, P., Dickey, J.T., Campbell, B., 2003. Biochemistry and physiology of fish gonadotropins. Fish Physiol. Biochem. 28, 53-59. https://doi.org/10.1023/B:FISH.0000030476.73360.07

Swanson, P., Suzuki, K., Kawauchi, H., Dickhoff, W.W., 1991. Isolation and characterization of two coho salmon gonadotropins, GTH I and GTH II. Biol. Reprod. 44, 29-38. https://doi.org/10.1095/biolreprod44.1.29

Taylor, E.B., 1991. A review of local adaptation in Salmonidae, with particular reference to Pacific and 
Atlantic salmon. Aquaculture 98, 185-207. https://doi.org/10.1016/0044-8486(91)90383-i

\section{7}

548

549

550

Vandesompele, J., De Preter, K., Pattyn, I., Poppe, B., Van Roy, N., De Paepe, A., Speleman, R., 2002. Accurate normalization of real-time quantitative RT-PCR data by geometric averaging of multiple internal control genes. Genome Biol. 3, 31-34. https://doi.org/10.1186/gb-2002-3-7-research0034

Weltzien, F.A., Andersson, E., Andersen, Ø., Shalchian-Tabrizi, K., Norberg, B., 2004. The brain-pituitarygonad axis in male teleosts, with special emphasis on flatfish (Pleuronectiformes). Comp. Biochem. Physiol. - A Mol. Integr. Physiol. 137, 447-477. https://doi.org/10.1016/j.cbpb.2003.11.007

Weltzien, F.A., Pasqualini, C., Vernier, P., Dufour, S., 2005. A quantitative real-time RT-PCR assay for European eel tyrosine hydroxylase, in: General and Comparative Endocrinology. Academic Press, pp. 134-142. https://doi.org/10.1016/j.ygcen.2004.12.019

Xiong, F., Chin, R., Gong, Z., Suzuki, K., Kitching, R., Majumdar-Sonnylal, S., Elsholtz, H.P., Hew, C.L., 1993. Control of salmon pituitary hormone gene expression. Fish Physiol. Biochem. 11, 63-70. https://doi.org/10.1007/BF00004551

Yaron, Z., Gur, G., Melamed, P., Rosenfeld, H., Elizur, A., Levavi-Sivan, B., 2003. Regulation of fish gonadotropins. Int. Rev. Cytol. 225, 131-185. https://doi.org/10.1016/S0074-7696(05)25004-0

Ye, J., Coulouris, G., Zaretskaya, I., Cutcutache, I., Rozen, S., Madden, T.L., 2012. Primer-BLAST: a tool to design target-specific primers for polymerase chain reaction. BMC Bioinformatics 13, 134 . https://doi.org/10.1186/1471-2105-13-134 


\section{Tables}

566 Table 1 Summary of morphometric measurement, steroid plasma levels and relative mRNA 567 abundance in one-year old male parr measured in the present study. mRNA levels are represented 568 as fold induction to the lowest point. (K) condition factor (m) maturing (i) immature (SD) standard 569 deviation (ND) not detected (NA) not available.

\begin{tabular}{|c|c|c|c|c|c|c|c|}
\hline & & & & & \\
\hline & & & $25 \mathrm{Apr}$ & 8 May & 23 May & 7 Jun & $4 \mathrm{Jul}$ \\
\hline \multirow{6}{*}{$\begin{array}{l}\text { Fork } \\
\text { length } \\
(\mathrm{cm})\end{array}$} & \multirow{3}{*}{$\mathrm{m}$} & mean & 10.63 & 10.01 & 11.57 & 12.72 & 13.55 \\
\hline & & SEM & 0.23 & 0.35 & 0.40 & 0.35 & 0.33 \\
\hline & & replicates & 7 & 7 & 7 & 12 & 6 \\
\hline & \multirow{3}{*}{$\mathrm{i}$} & mean & 9.23 & 9.07 & 9.67 & 10.70 & \multirow{2}{*}{ NA } \\
\hline & & SEM & 0.37 & 0.27 & 0.31 & - & \\
\hline & & replicates & 7 & 6 & 6 & 1 & 0 \\
\hline \multirow{6}{*}{$\begin{array}{l}\text { Body } \\
\text { weight } \\
\text { (cm) }\end{array}$} & \multirow{3}{*}{$\mathrm{m}$} & mean & 12.62 & 11.46 & 18.67 & 26.10 & 31.98 \\
\hline & & SEM & 1.33 & 1.13 & 2.34 & 2.62 & 2.42 \\
\hline & & replicates & 7 & 8 & 7 & 12 & 6 \\
\hline & \multirow{3}{*}{$\mathrm{i}$} & mean & 7.82 & 7.37 & 9.10 & 10.90 & \multirow{2}{*}{ NA } \\
\hline & & SEM & 0.89 & 0.58 & 1.21 & - & \\
\hline & & replicates & 7 & 6 & 6 & $\overline{1}$ & 0 \\
\hline \multirow{6}{*}{ GSI } & \multirow{3}{*}{$\mathrm{m}$} & mean & 0.236 & 0.392 & 0.375 & 0.401 & 0.852 \\
\hline & & SEM & 0.064 & 0.142 & 0.099 & 0.048 & 0.132 \\
\hline & & replicates & 7 & 8 & 7 & 12 & 6 \\
\hline & \multirow{3}{*}{$\mathrm{i}$} & mean & 0.042 & 0.040 & 0.021 & 0.037 & \multirow{2}{*}{ NA } \\
\hline & & SEM & 0.004 & 0.007 & 0.005 & - & \\
\hline & & replicates & 7 & 6 & 6 & 1 & 0 \\
\hline \multirow{6}{*}{ K } & \multirow{3}{*}{$\mathrm{m}$} & mean & 1.03 & 1.06 & 1.15 & 1.21 & 1.27 \\
\hline & & SEM & 0.05 & 0.03 & 0.04 & 0.04 & 0.02 \\
\hline & & replicates & 7 & 7 & 7 & 12 & 6 \\
\hline & \multirow{3}{*}{$\mathrm{i}$} & mean & 0.98 & 0.98 & 0.97 & 0.89 & \multirow{2}{*}{ NA } \\
\hline & & SEM & 0.05 & 0.03 & 0.05 & - & \\
\hline & & replicates & 7 & 6 & 6 & 1 & 0 \\
\hline \multirow{6}{*}{$\begin{array}{l}11 \mathrm{KT} \\
(\mathrm{ng} / \mu \mathrm{l})\end{array}$} & \multirow{3}{*}{$\mathrm{m}$} & mean & 0.09 & 0.13 & 0.23 & 0.46 & 2.07 \\
\hline & & SEM & 0.09 & 0.08 & 0.14 & 0.11 & 0.57 \\
\hline & & replicates & 7 & 7 & 7 & 12 & 6 \\
\hline & & mean & ND & ND & ND & ND & NA \\
\hline & $\mathrm{i}$ & SEM & ND & ND & ND & ND & NA \\
\hline & & replicates & 7 & 5 & 6 & 1 & 0 \\
\hline \multirow{6}{*}{$\begin{array}{l}\mathrm{T} \\
(\mathrm{ng} / \mu \mathrm{l})\end{array}$} & \multirow{3}{*}{$\mathrm{m}$} & mean & 0.74 & 0.96 & 1.11 & 1.27 & 1.72 \\
\hline & & SEM & 0.07 & 0.10 & 0.09 & 0.14 & 0.16 \\
\hline & & replicates & 6 & 7 & 7 & 12 & 6 \\
\hline & \multirow{3}{*}{$\mathrm{i}$} & mean & 0.35 & 0.22 & 0.34 & \multirow{2}{*}{ NA } & \multirow{2}{*}{ NA } \\
\hline & & SEM & 0.15 & 0.13 & 0.10 & & \\
\hline & & replicates & 6 & 5 & 4 & 0 & 0 \\
\hline
\end{tabular}


571 Table 2 Summary of morphometric measurement, steroid plasma levels and relative mRNA 572 abundance in under-yearling male parr measured in the present study. mRNA levels are 573 represented as fold induction to the lowest point. $(\mathrm{K})$ condition factor $(\mathrm{m})$ maturing (i) immature 574 (SD) standard deviation (ND) not detected (NA) not available.

\begin{tabular}{|c|c|c|c|c|c|c|}
\hline & & & 4-Jul & 22-Aug & 27-Sep & 23 -Oct \\
\hline \multirow{6}{*}{$\begin{array}{l}\text { Fork } \\
\text { length } \\
\mathrm{cm}\end{array}$} & \multirow{3}{*}{$\mathrm{m}$} & mean & & & 9,48 & 10,00 \\
\hline & & SEM & & & 0.33 & 0.31 \\
\hline & & replicates & & & 5 & 9 \\
\hline & \multirow{3}{*}{$\mathrm{i}$} & mean & 6,00 & 9,50 & 11,32 & 9,91 \\
\hline & & SEM & 0.18 & 0.25 & 0.32 & 0.60 \\
\hline & & replicates & 5 & 6 & 9 & 8 \\
\hline \multirow{6}{*}{$\begin{array}{l}\text { Body } \\
\text { weight } \\
\mathrm{cm}\end{array}$} & \multirow{3}{*}{$\mathrm{m}$} & mean & & & 8,92 & 10,66 \\
\hline & & SEM & & & 0.87 & 1.10 \\
\hline & & replicates & & & 5 & 9 \\
\hline & \multirow{3}{*}{$\mathrm{i}$} & mean & 2,34 & 9,70 & 16,19 & 12,00 \\
\hline & & SEM & 0.21 & 0.93 & 1.34 & 0.95 \\
\hline & & replicates & 5 & 6 & 9 & 8 \\
\hline \multirow{6}{*}{ GSI } & \multirow{3}{*}{$\mathrm{m}$} & mean & & & 0.168 & 1.710 \\
\hline & & SEM & & & 0.059 & 0.945 \\
\hline & & replicates & & & 5 & 9 \\
\hline & \multirow{3}{*}{$\mathrm{i}$} & mean & 0.010 & 0.026 & 0.034 & 0.034 \\
\hline & & SEM & 0.003 & 0.002 & 0.003 & 0.005 \\
\hline & & replicates & 5 & 6 & 9 & 8 \\
\hline \multirow{6}{*}{ K } & \multirow{3}{*}{$\mathrm{m}$} & mean & & & 1.03 & 1.04 \\
\hline & & SEM & & & 0.02 & 0.02 \\
\hline & & replicates & & & 5 & 9 \\
\hline & \multirow{3}{*}{$\mathrm{i}$} & mean & 1,07 & 1.11 & 1.09 & 1.50 \\
\hline & & SEM & 0.05 & 0.02 & 0.02 & 0.41 \\
\hline & & replicates & 5 & 6 & 8 & 8 \\
\hline
\end{tabular}


576 Table 3 Primers used in the present study.

\begin{tabular}{|l|l|l|l|c|c|}
\hline Gene & Accession number & Primer FW (5'-3') & Primer RW (5'-3') & Product size (bp) & Efficiency (\%) \\
$l h b$ & NM_001173671.1 & GTCACAGCTCAGAGCCACAG & GACGTCCGCTATGAAACGAT & 97 \\
$f s h b$ & XM_014126338.1 & TACCTGGAAGGCTGTCCATC & TATGCGATCACAGTCGGTGT & 101 & 99 \\
$r n a 18 s$ & FJ710886.1 $\dagger$ & CTCAACACGGGAAACCTCAC & AGACAAATCGCTCCACCAAC & 118 & 99.5 \\
$e f 1 a$ & NM_001141909.1 & CTTTGTGCCCATCTCTGGAT & ACCCTCCTTACGCTCGACTT & 97 \\
\hline
\end{tabular}

$577 \quad \dagger$ Primers from Maugars and Schmitz (2006). 
578 Table 4 Stages of testes development used for histological analysis. Each stage is defined by the 579 most developed germ cell cyst present in the testis tissue. SPA, spermatogonia A, either 580 undifferentiated or differentiated; SPB, spermatogonia B; SC, spermatocytes; ST, spermatids; SZ, 581 spermatozoa.

\begin{tabular}{|ll|}
\hline Stages & Observed cysts \\
I & SPA \\
III & SPA+SPB \\
IV & SPA+SPB+SC+ST \\
V & SPA+SPB+SC+ST+SZ \\
& (With some tubules still immature, or early maturing) \\
VI & SZ is dominating. Large lumen in tubules \\
\hline
\end{tabular}




\section{Figures}
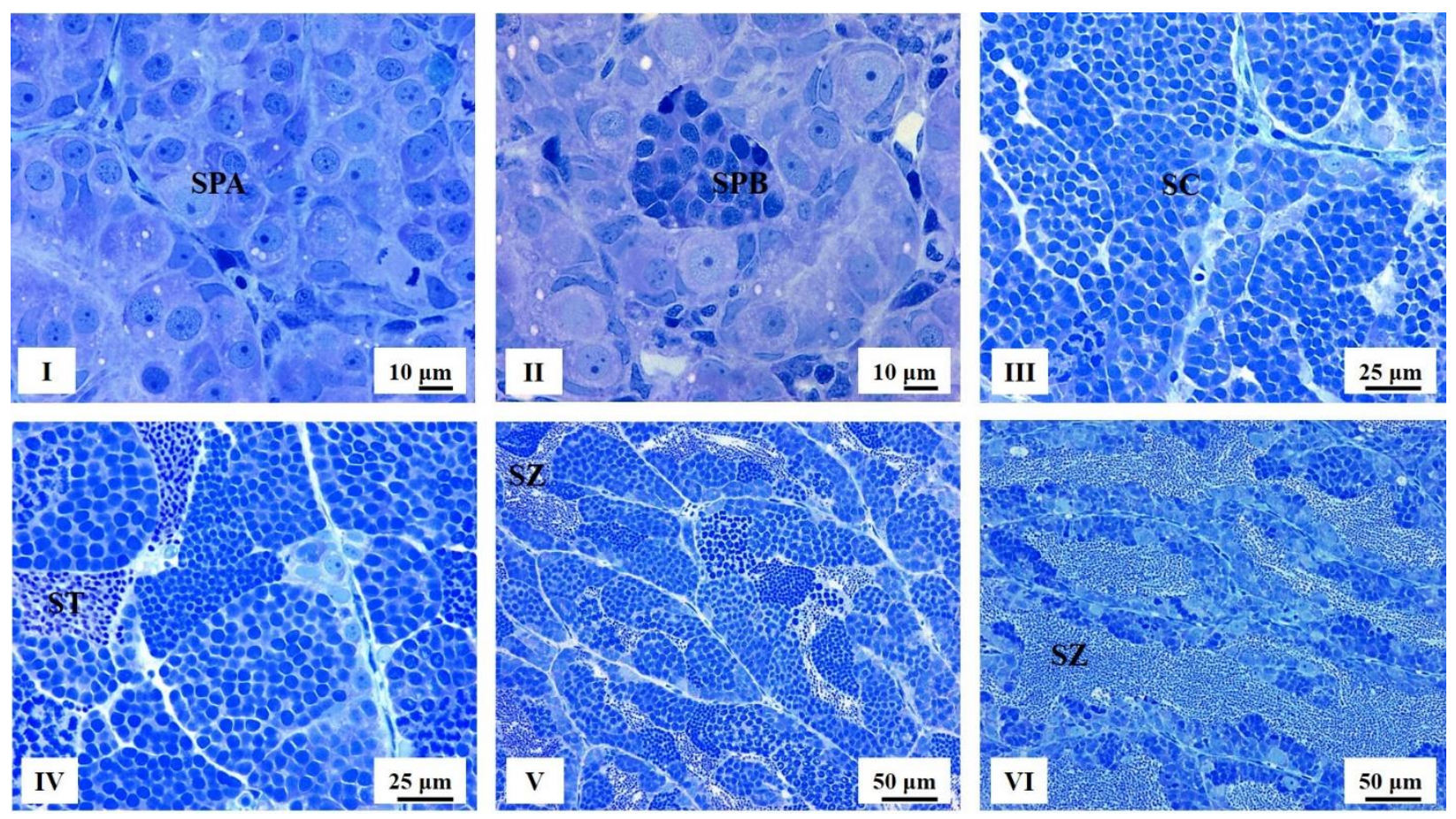

586 Figure 1. Testis developmental stages in Atlantic salmon parr defined according to the most 587 advanced cyst present: Stage I, spermatogonia A (SPA) predominate, either undifferentiated or 588 differentiated; Stage II, occurrence of spermatogonia B (SPB); Stage III, spermatocytes (SC) 589 present; Stage IV, spermatids (ST) present; Stage V, first signs of spermatozoa (SZ), with some 590 tubules still immature, or early maturing. Stage VI, spermatozoa dominate in all tubules. Large 591 lumen in tubules. Sections $(3 \mu \mathrm{m})$ were prepared in plastic resin and stained with Toluidine Blue 592 O. 

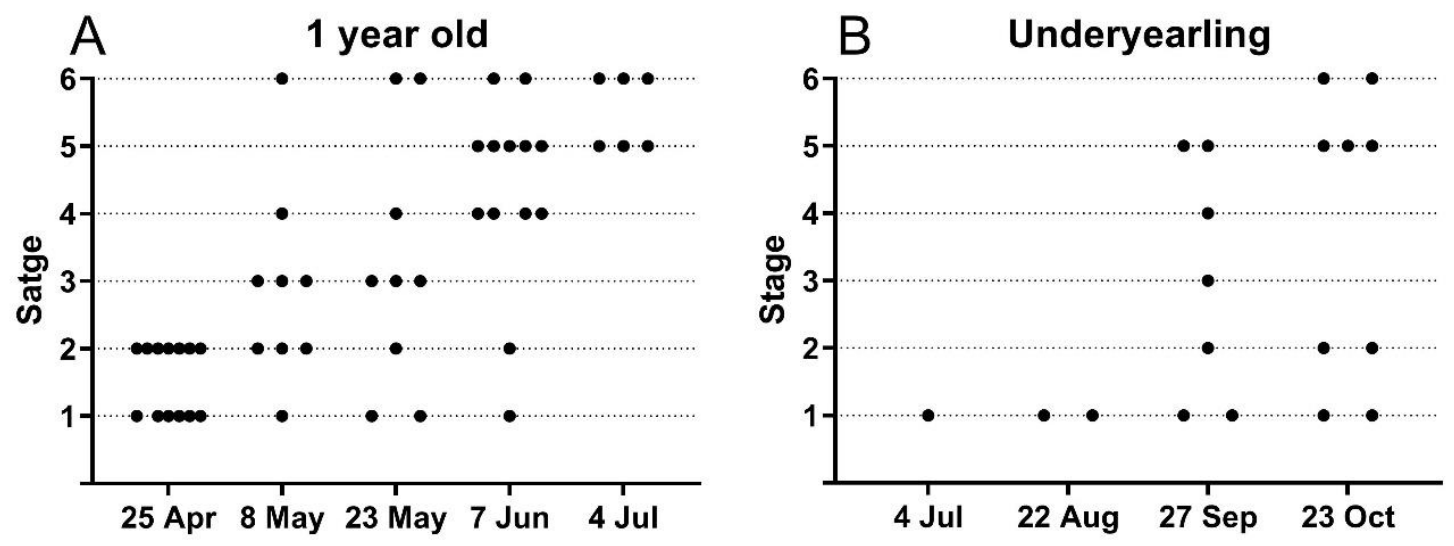

594 Figure 2. Advancement in testis developmental stages in A) one-year old and B) under-yearling 595 male parr in spring/autumn. Each dot represents the testis developmental stage assigned according 596 to the most developed cyst detected. Testes of all maturing and a few randomly selected non597 maturing males were analysed at each date. 

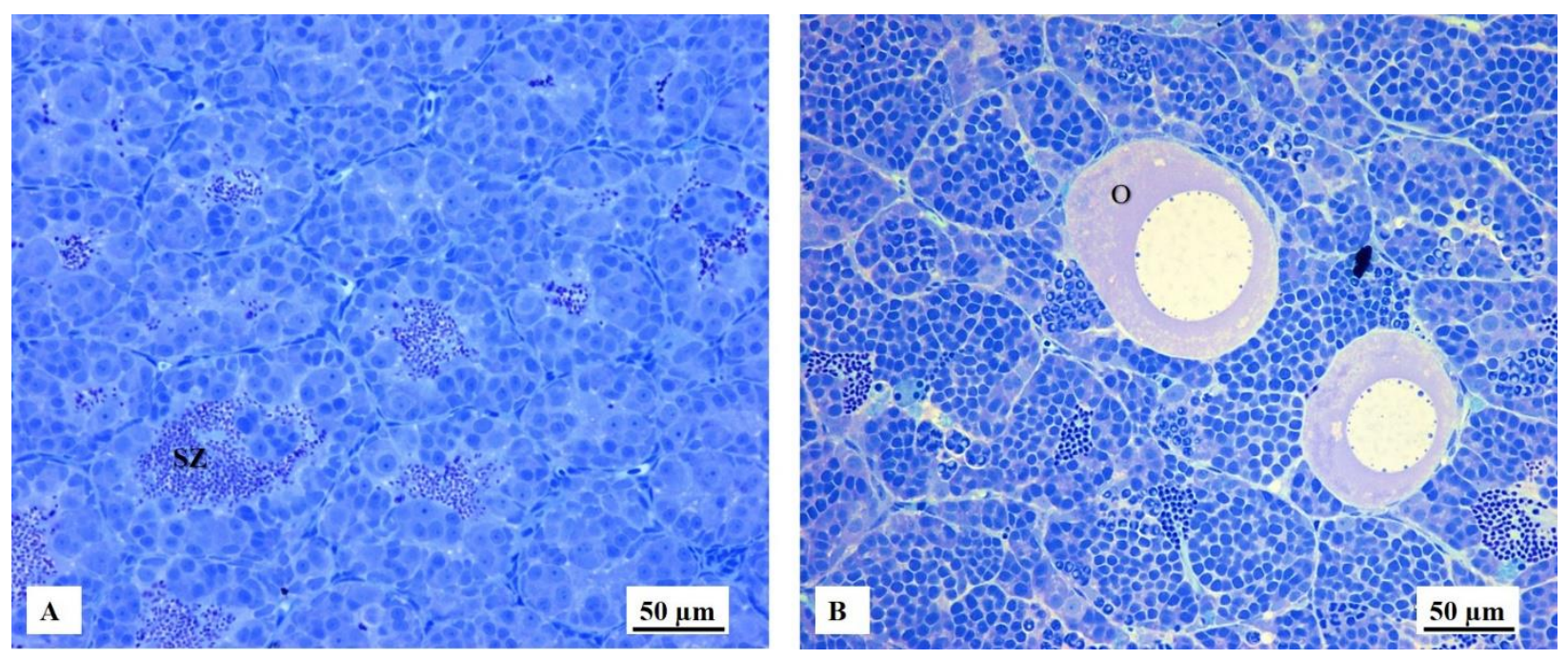

599 Figure 3. Sections of testes showing A) residual spermatozoa (SZ) and B) early previtellogenic 600 oocytes $(\mathrm{O})$. Sections $(3 \mu \mathrm{m})$ were prepared in plastic resin and stained with Toluidine Blue O. 

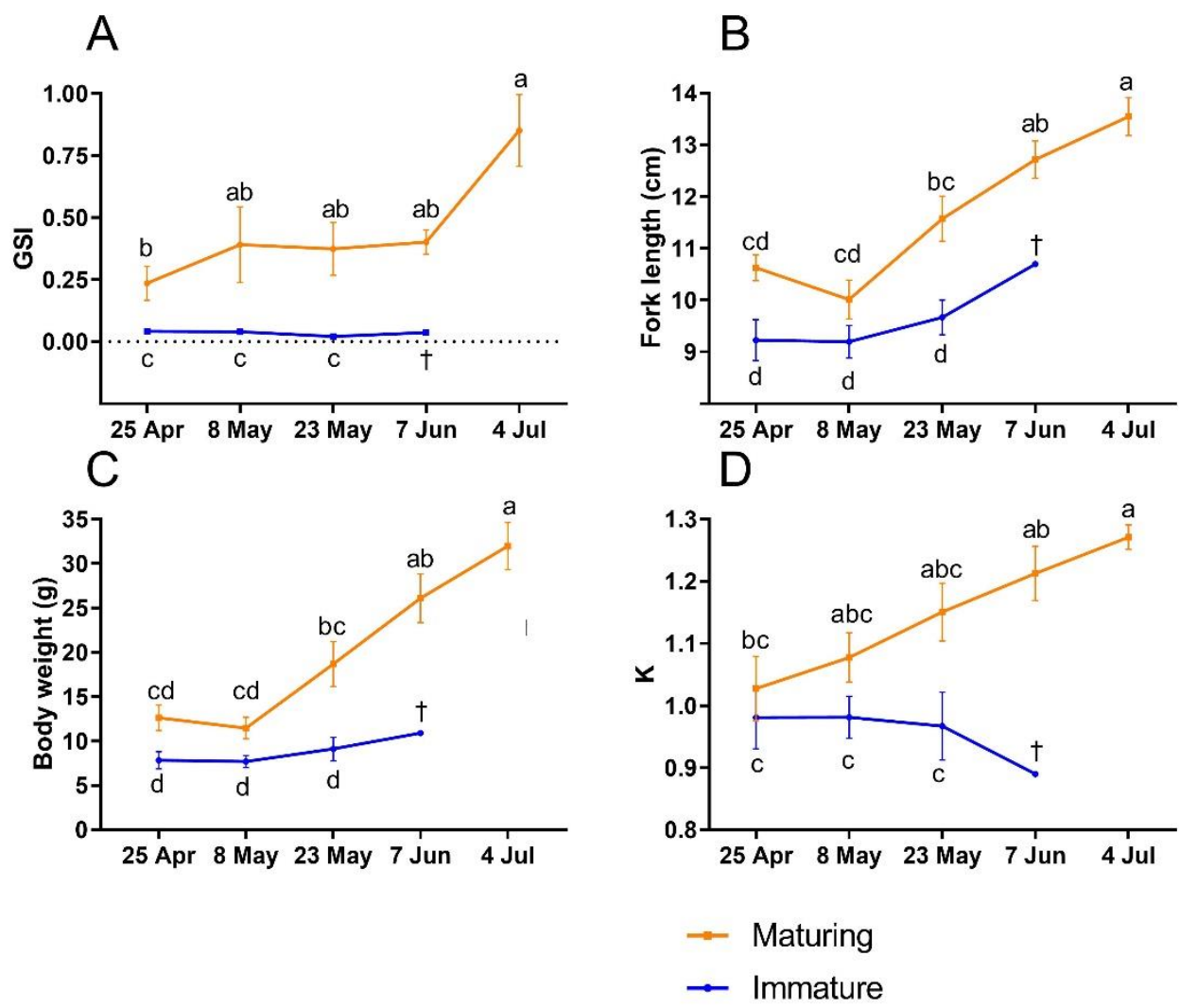

602 Figure 4. Morphometric measurements of one-year old male parr during spring/summer. A) 603 gonadosomatic index (GSI = gonad weight/body weight*100); B) Fork length (L); C) body weight $604(\mathrm{~W})$; D) condition factor $\left(\mathrm{K}=100 \mathrm{~W} / \mathrm{L}^{3}\right)$. Data are presented as mean \pm SEM. Distinct letters denote 605 statistically significant differences among groups $(\mathrm{p}<0.05)$, analysed via two-way ANOVA 606 followed by Tukey multiple comparison test. $\uparrow$ Only one immature fish was available on June $7^{\text {th }}$. 607 It is presented for graphical purposes only and is not included in the statistical analysis. The 608 number of biological replicates per data point is listed in table 1. 
A
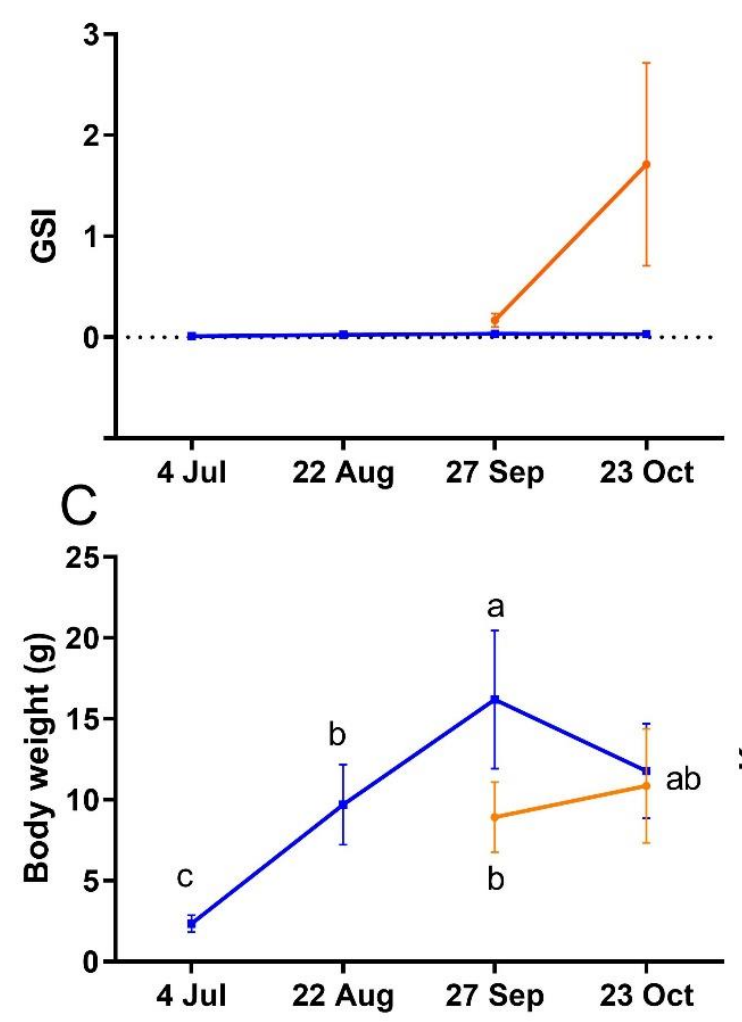

B
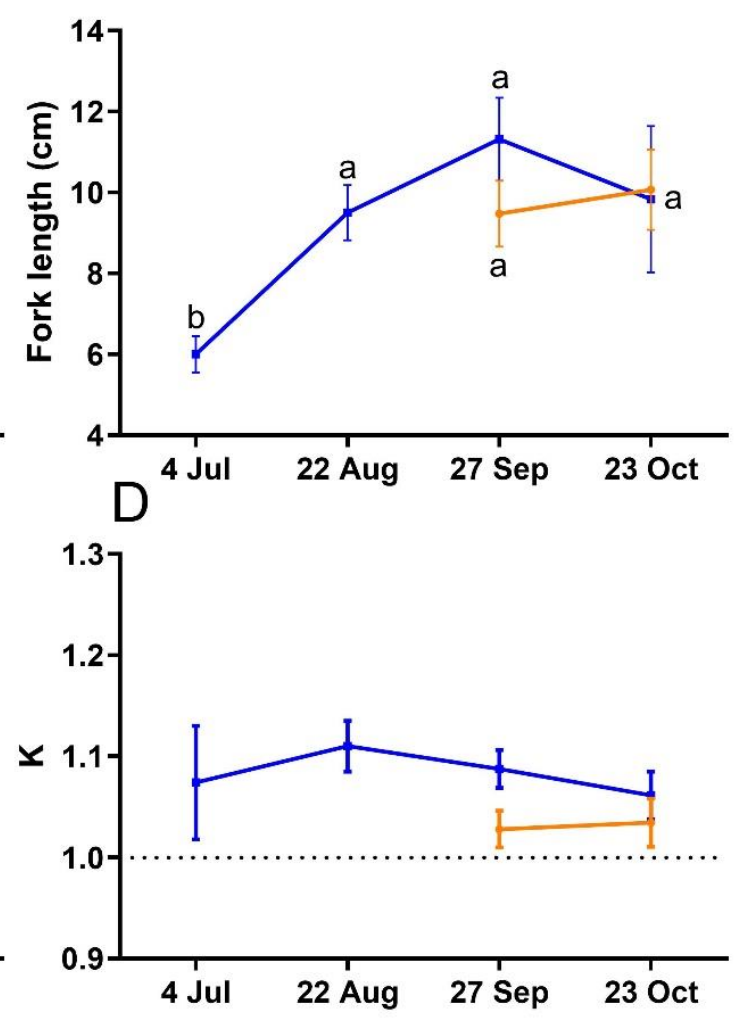

609

\section{$\rightarrow$ Maturing}

$\rightarrow$ Immature

610 Figure 5. Morphometric measurements of under-yearling male parr during summer/autumn. A) 611 Gonadosomatic index (GSI= gonad weight/body weight*100); B) Fork length (L); C) Body weight

612 (W); D) Condition factor $\left(\mathrm{K}=100 \mathrm{~W} / \mathrm{L}^{3}\right)$; Data are shown as mean \pm SEM. Distinct letters denote 613 statistically significant differences among groups $(\mathrm{p}<0.05)$, analysed via two-way ANOVA 614 followed by Tukey multiple comparison test. The number of biological replicates per point is listed 615 in table 2. 

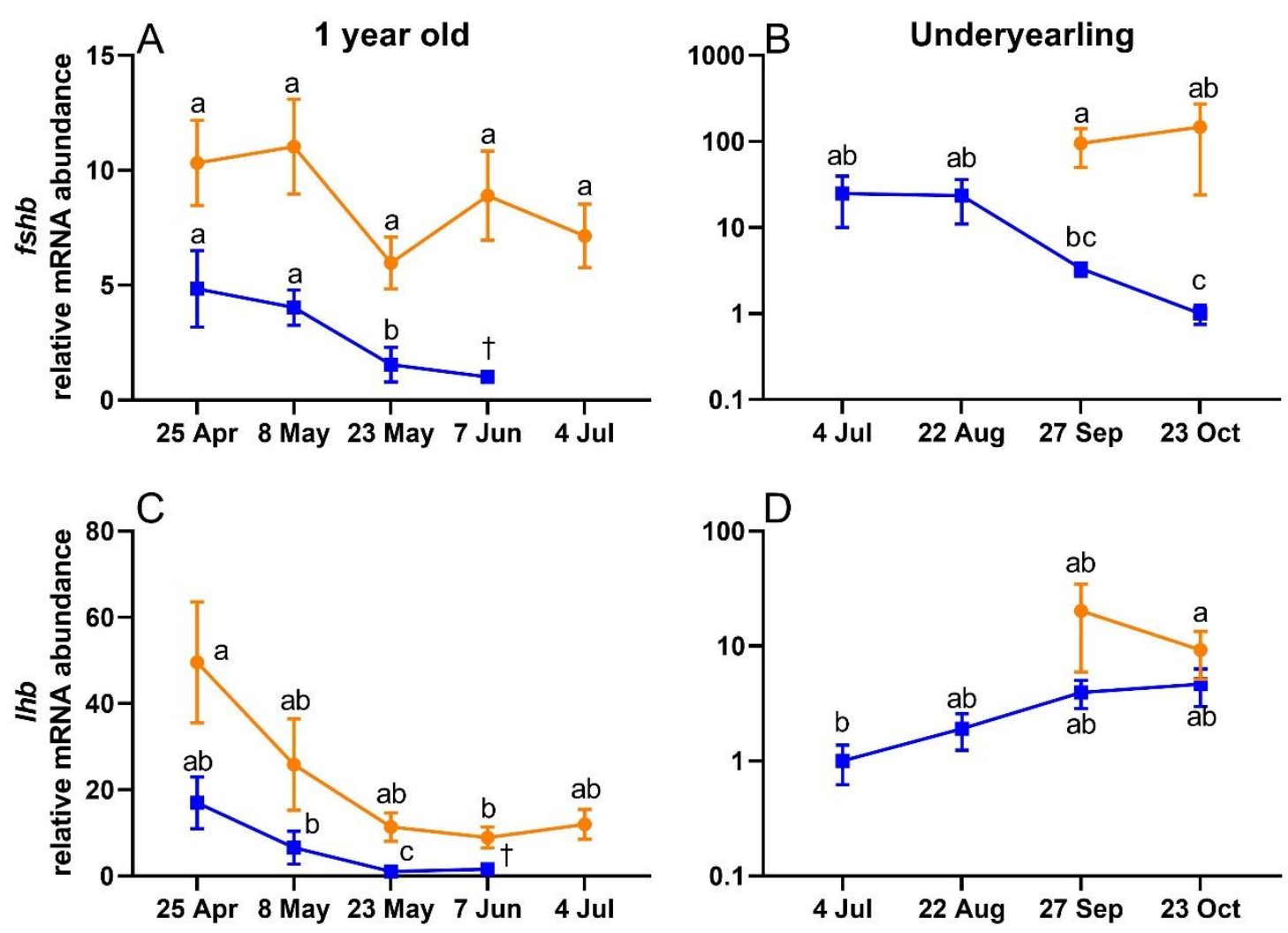

616

617 Figure 6. Relative abundance of: A-B) $f s h b$ and C-D) $l h b$ mRNA in pituitaries from A-C) one618 year old and B-D) under-yearling male Atlantic salmon parr. Data are graphically presented as 619 fold change of the lowest expressing point (set as value 1) (mean \pm SEM; $n=6$ ). Distinct letters 620 denote statistically significant differences among groups ( $\mathrm{p}<0.05)$, analysed via two-way ANOVA 621 followed by Tukey multiple comparison test. mRNA levels are normalized againstrna 18 s and efla.

$622 \dagger$ Only one immature fish was available on June $7^{\text {th }}$. It is presented for graphical purposes only and 623 is not included in the statistical analysis. 

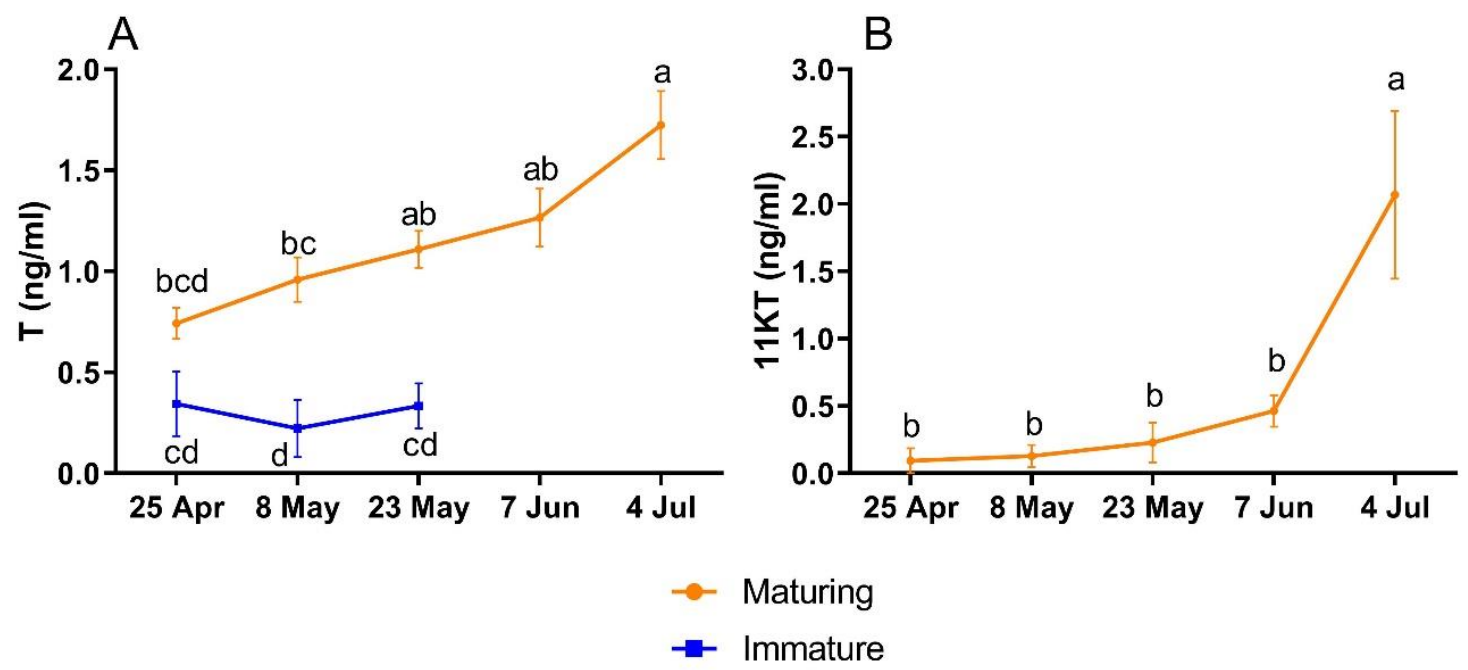

625 Figure 7. A) Testosterone (T) and B) 11-ketotestosterone (11-KT) plasma levels in one-year old 626 male parr. Data are presented as mean \pm SEM. Distinct letters denote statistically significant 627 differences among groups ( $<<0.05)$, analysed via two-way ANOVA followed by Tukey multiple 628 comparison test. Plasma 11-KT was not detected in immature fish. The number of biological 629 replicates per point is listed in table 1. 

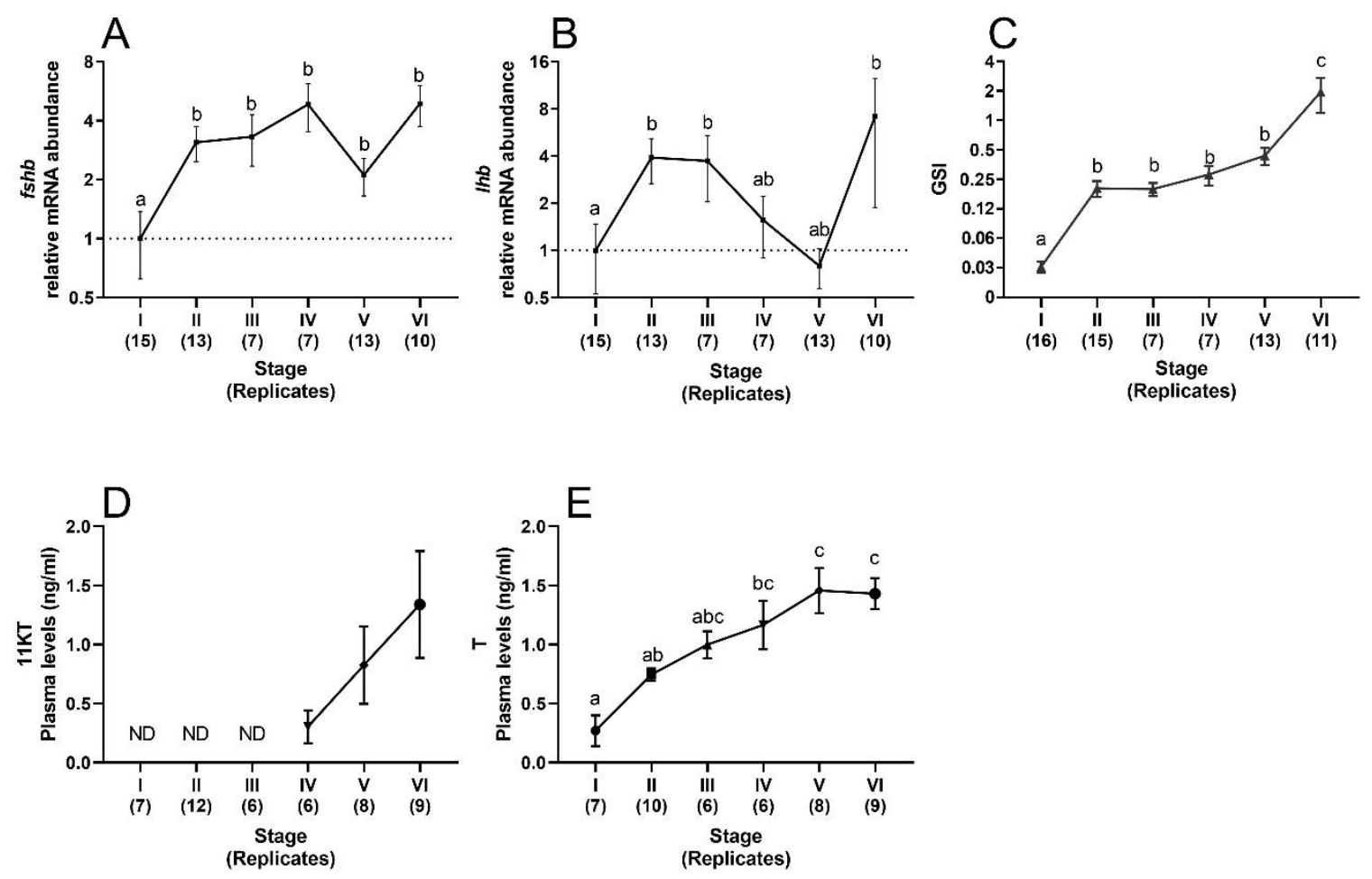

631 Figure 8. Changes in A) $f s h b, \mathbf{B}) l h b, \mathbf{C})$ GSI, D) 11-ketotestosterone (11KT), E) testosterone (T), according to testis developmental stages I-VI. The transcript abundance $(f s h b, l h b)$ of stage I fish was set as value 1 for the representation and the following stages are represented as fold-induction. mRNA levels were normalized against rnalss and efla. Data are presented as mean \pm SEM from 635 pooled under-yearling and one-year old fish. Distinct letters denote statistically significant differences among groups $(\mathrm{p}<0.05)$, analysed via one-way ANOVA, followed by Tukey multiple 637 comparison test. The number of available biological replicates available for each variable is shown 638 below each stage. ND; not detected. 


\section{Supplementary files}

640 Figure S1. Natural photoperiod at Ims, Norway (black line; 58 $54^{\prime} \mathrm{N}, 5^{\circ} 57^{\prime} \mathrm{E}$ ) and at the Norrfors 641 hatchery, Sweden (red dotted line; $63^{\circ} \mathrm{N}, 20^{\circ} \mathrm{E}$ ) where the studies from (Maugars and Schmitz, 642 2008; Mayer et al., 1990b) were performed. Y axes indicates time of the day. Sunrise and sunset 643 time represented from lower and upper line respectively. Data were retrieved from 644 www.timeanddate.com

645 Figure S2. Seasonal changes in water temperature at Ims research station (black line; $58^{\circ} 54^{\prime} \mathrm{N}$, $6465^{\circ} 57^{\prime} \mathrm{E}$ ) from 2015 to 2017 . Water temperature at Norrfors hatchery (red dotted line; $63^{\circ} \mathrm{N}, 20^{\circ} \mathrm{E}$ ) 647 in 2003 where the studies from (Maugars and Schmitz, 2008; Mayer et al., 1990b) was performed. 648 Temperature data from Norrfors hatchery were kindly provided from Dr. Gersende Maugars.

649 Figure S3. Sagittal section showing incomplete maturation of salmon testis, where only parts of 650 the tissue is maturing. Sections $(3 \mu \mathrm{m})$ were prepared in plastic resin and stained with Toluidine 651 Blue O. Scale bar $100 \mu \mathrm{m}$. 